kolejności, a następnie zadośćuczynienie jej potrzebom drugorzędnym”. Tym samym rozpoczął budowę teorię opieki. Podjął się również określenia pedagogiki opiekuńczej, a jej rozumienie oparł na źródłowym odniesieniu do sytuacji opiekuńczej i wychowawczej.

Według Grzegorz Grzybka „Pedagogika opiekuńcza to dziedzina pedagogiki, która koncentruje się na analizie sytuacji opiekuńczej i jej związków z sytuacja wychowawcza, gdzie podstawowe odniesienie aksjologiczno-normatywne opiera się na troskliwości i etosie opiekuńczym".

Książka jest konsekwentną i interesująca próbą odpowiedzi na postawiony w pracy problem: „do jakich wartości i norm należy odwołać się przy konstruowaniu podstaw teoretycznych dla zagadnień opiekuńczych?” Pokazał siłę wyjaśniająca założeń, że wartościami podstawowymi są wolność i godność osoby, zaś normami-zasadami wyznaczającymi zadania opiekuńcze: etos opiekuńczy i troskliwość.

Wiesław Wójcik*

Centrum Studiów nad Szkołą Katolicką (red.), L’impegno delle Chiese Locali. Scuola Cattolica in Italia. Tredicesimo Rapporto, 2011 (Zadanie Kościołów lokalnych. Szkoła Katolicka we Wtoszech. Trzynasty Raport, 2011), La scuola, Brescia 2011, ss. 352.

DOI: http://dx.doi.org/10.12775/PCh.2013.020

Publikacja Zadanie Kościołów lokalnych. Szkoły Katolickie we Włoszech jest już trzynastym raportem przedstawionym przez Centrum Studiów nad Szkołą Katolicką. Centrum to funkcjonuje w ramach działań edukacyjnych Komisji Episkopatu Włoch. Każdego roku pogłębiane są różne tematy o wychowaniu i szkolnictwie katolickim, których badania stanowią cenny wkład w edukację Włoską, ale również mają wpływ na wizję edukacyjną w Europie i Kościele powszechnym. Prezentowana publikacja o szkołach katolickich ma swoje odniesienie do dokumentu Komisji Episkopatu Włoch zatytułowanego Kierunki Duszpasterskie na dziesięciolecie 2010-2020 pt. Wychowywać do dobrego życia Ewangeliq. ${ }^{1}$ W dokumencie

* Dr hab. Wiesław Wójcik, prof. PAN, WSA, jest profesorem Instytutu Historii Nauki Polskiej Akademii Nauk, kieruje również Zakładem Pedagogiki Rodziny i Pracy Socjalnej Wydziału Nauk Humanistycznych i Społecznych Wyższej Szkoły Administracji w Bielsku-Białej.

1 Wskazówki Duszpasterskie [Orientamenti Pastorali] jest to dokument Kościoła Włoskiego na dziesięciolecie 2010-2020. Ukazuje on linie harmonijnego wzrostu Kościoła we Włoszech w aspekcie edukacji. Edukację Biskupi włoscy uznali bowiem za współczesne wyzwanie kulturowe i znak czasów. Jest ona uważana za trwały i konstytutywny wymiar misji 
tym pojawiają się wskazania na linie działań Kościoła włoskiego w sektorze edukacji.

W myśl wskazówek biskupów włoskich Centrum Studiów nad Szkoła Katolicką w Rzymie przedstawia zadania Kościołów lokalnych względem szkolnictwa katolickiego we Włoszech. W publikacji tej autorzy ukazują kompleksowe podstawy oraz propozycje działań w życiu Kościoła lokalnego. Jedną z misji Kościoła jest opieka nad szkołami katolickimi. Są one traktowane jako instytucje edukacyjne i kulturowe w społeczności chrześcijańskiej. Szkoły katolickie wpisane są jednocześnie w duszpasterstwo młodzieży, które jest ściśle zintegrowane z duszpasterstwem na terenie diecezji w Italii. Dlatego szkołę katolicką możemy uznawać za jeden z ważnych sektorów duszpasterskich współczesnego Kościoła. Na podstawie badań zauważa się jednak, że nie zawsze wspomniane duszpasterstwo jest odpowiednio rozpoznawane w kluczu diecezjalnego duszpasterstwa młodzieżowego. Prezentowana książka ma zatem na celu podjęcie refleksji na temat relacji pasterzy kościoła do szkolnictwa katolickiego i realizacji celów duszpasterskich. Pracownicy Centrum Studiów nad Szkolnictwem Katolickim poświęcili 13-ty raport relacji pomiędzy Kościołem lokalnym i szkołami katolickimi, przedstawiając głównie możliwości rozwoju i szanse szerszej współpracy.

Publikacja jest podzielona na trzy części, w których poruszono różne tematy. W sposób szczególny są analizowane teoretyczne przesłanki badań we wspomnianym sektorze. Znaczącą wartością książki jest bogaty dodatek statystyczny, który realnie uwidacznia aktualny stan szkolnictwa katolickiego we Włoszech.

Pierwsza część publikacji ukazuje „środek ciężkości” duszpasterstwa Kościoła i szkoły katolickiej, który według autorów będzie miał swój większy wymiar w przyszłości, jako jedna całość duszpasterska. Mówi się bowiem o misyjności Kościoła, przez którą kształtowana jest nowa świadomość dynamicznego charakteru chrześcijaństwa. Charakter ten odzwierciedla łaskę i zbawienie, a sam Kościół postrzegany jest jako zjawisko społeczne, które znajduje swoje źródło i aspekt konstytutywny w miłości Boga do człowieka.

Pierwszą część rozpoczyna rozdział, który próbuje określić i opisać obecność szkół katolickich w diecezjach w świetle najnowszego nauczania Kościoła. Autor tegoż rozdziału, Sergio Cicatelli, pokazuje szkołę katolicką

Kościoła w świecie. Temat edukacji wielokrotnie podejmował Papież Benedykt XVI, którego nauczanie jest odniesieniem i źródłem inspiracji do przekazania niektórych wniosków dla duszpasterstwa szkolnego we Włoszech. Por. Conferenza Episcopale Italiana, Educare alla vita buona del Vangelo, Orientamenti pastorali dell'Episcopato italiano per il decennio 2010-2020, Paolone, Milano 2010. [Konferencja Episkopatu Włoch, Wychowywać do dobrego życia Ewangeliq. Wskazówki duszpasterskie Episkopatu włoskiego na dziesięciolecie 2010-2020, Paolone, Mediolan 2010]. 
jako jeden ze sposobów wyrażenia wspólnoty chrześcijańskiej. Podkreśla jednocześnie jej istotną obecność na terenie diecezji. Porusza ten temat, ponieważ w rzeczywistości lokalnej punktem zwrotnym są decyzje duszpasterskie poszczególnych biskupów i współpraca z krajowym i diecezjalnymi biurami duszpasterskimi. Na terenie diecezji biura te, według autora, winny być aktywowane lub reaktywowane, aby szczególnej zająć się pracą pastoralną i animacją szkół katolickich. Tak biura ds. Szkolnictwa Katolickiego, jak i same szkoły są powołane, aby odpowiadać na współczesne wyzwania pluralizmu kulturowego. Zachęca on Kościół do wzmożenia wysiłków na rzecz edukacji i tworzenia silnych osobowości, zdolnych do odpowiedniej reakcji na wpływ relatywizmu wiary, a jednocześnie do pełnej realizacji misji chrześcijańskiej w świecie.

Drugie studium, przedstawione przez Maurizio Viviani, dąży do rekonstrukcji procedur stosowanych przez Komisję Episkopatu Włoch w organizowaniu sektora szklono-edukacyjnego. W rozdziale tym analizuje się organizacyjny aspekt tego szkolnictwa od czasu jego powstania aż do dzisiaj. Autor omawia w nim pracę krajowych i diecezjalnych biur ds. szkolnictwa i ich działalność duszpasterską. Przedstawia przy tym narzędzia komunikacyjne, które służą przekazywaniu informacji na poziomie krajowym i lokalnym. Viviani podzielił szkolnictwo na trzy sektory: „szkolny”, „uniwersytecki” i „edukację”. Według niego podział ten wzmacnia każdy sektor i rozszerza horyzonty poznawcze.

W trzecim rozdziale Agostino Montan określił rolę biskupa w zakresie duszpasterstwa ogólnego i szkolno-edukacyjnego w diecezji. Podkreśla on charakter duszpasterski wynikający z prawa kanonicznego i Magisterium Kościoła. Skupia się na analizie zadań pasterza diecezji, zauważając linię ewolucyjna, słabości i postęp na tym obszarze. Zwraca uwagę na środki używane przez biskupa w celu interwencji edukacyjnej. Do najbardziej praktycznych zaliczone są „nauczanie”, „doradztwo”, „nakłanianie do oddanej pracy na rzecz młodzieży” oraz „wymogi normatywne”. Dzięki tym środkom biskupi próbują rozwijać syntezę pomiędzy kulturą a wiarą oraz wiarą i życiem. Integrując w ten sposób różne aspekty ludzkiej wiedzy w świetle Ewangelii, aby kształcić i wychować uczciwego człowieka i dobrego chrześcijanina.

Druga część pracy jest refleksją nad rozpowszechnianiem „kultury wiary”. W tej kwestii można i należy spodziewać się znaczącego wkładu ze strony szkół katolickich, które nie tylko zachowały, ale również odnowiły metody i sposób podejścia do współczesnej kultury i nauk pedagogicznych oraz doskonalenia zawodowego nauczycieli. Rozpoczyna ją komentarz do danych pochodzących z biur diecezjalnych ds. duszpasterstwa szkolnego. Zwraca się w nim uwagę na kwestionariusz, który został opracowany, aby 
„rzucić światło” na związek między działalnością duszpasterską Kościoła lokalnego a szkołami katolickimi znajdującymi się na jego terytorium. Guglielmo Malizia i Sergio Cicatelli przedstawiają strukturę biura ds. duszpasterstwa szkolnictwa katolickiego, jego organizację, zadania, koordynację i inicjatywy. Podkreślają potrzebę zwrócenia szczególnej uwagi na szkoły katolickie, ich ilość oraz konieczność odpowiedniego podejścia naukowego do tych instytucji. W analizie tej dostrzegane są pewne trudności w edukacji katolickiej i proponowane są środki zaradcze.

Kolejny, piąty rozdział został napisany przez grupę osób zajmujących się pracą w szkolnictwie. Do niej należą: Carmine Brienza, Maria Luisa de Natale, Michele Di Tolve, Vincenzo Annicchiarico i Giuseppe Ruta. Autorzy ci przedstawili konkretną praktykę duszpasterstwa szkolnego z perspektywy czterech różnych diecezji.

Pierwsza opisuje unikalne doświadczenia wielkiej Diecezji Rzymu, druga przedstawia współdziałanie duszpasterskie pomiędzy szkołami katolickimi i Katolickim Uniwersytetem Najświętszego Serca w Mediolanie. Zwraca się szczególną uwagę na istotę ewolucji w tym sektorze, choć nie zapomina się o słabych stronach duszpasterstwa ograniczających działania pastoralne. Do ograniczeń dołączone są wnioski niosące z sobą nowe możliwości pracy w duszpasterstwie szkolnym.

Trzeci opis przytacza współpracę Krajowego Biura ds. Nauczania Religii Katolickiej ze szkołą katolicką. Owa współpraca na terenie Włoch ma swój interesujący wymiar, bowiem nauczanie religii nie jest łączone z katechezą dzieci i młodzieży. Katechezę jako taką realizuje się w parafiach, a nauczanie religii katolickiej ma dostarczać uczniom kultury religijnej. Podkreśla się zatem, że wspomniane biura winny w podobny sposób promować kulturę religijną w Kościele i wzajemnie się uzupełniać.

Czwarty temat podjęty w tym rozdziale skupia się na doświadczeniach z zakresu kształcenia i formacji zawodowej, mającej swoje źródło w ogólnie pojętej misji Kościoła lokalnego. Przedstawione myśli zwracają uwagę na rolę ewangelizacji i edukacji. Ponadto, podkreśla się nadzieję odnowy oraz poszukiwania skutecznych środków w przekazywaniu wiary i kultury.

Trzecia część omawianej publikacji jest „bramą” do odkrywania tajników praktycznej działalności duszpasterskiej szkoły katolickiej i edukacji. Refleksja ta przedstawia obecne zagrożenia i wyzwania edukacyjne we Włoszech. Niestety, efekty badań aktualnego raportu nie przynoszą dobrych informacji i nie są dobrym znakiem żywotności Kościoła. Wynika z nich, że podstawowa opcja działalności pastoralnej szkolnictwa jest daleka od idealnej rzeczywistości włoskich diecezji. Wydaje się, że problemem jest coraz mniejsza liczba osób duchownych, które mogą się poświęcić działalności pastoralnej. Należy szukać odpowiedzi na pytanie, jak rozwiązywać 
problemy, z którymi na dzień dzisiejszy borykają się pastoraliści i pedagodzy. Jedną z możliwych odpowiedzi jest zaangażowanie osób świeckich, jednak według autorów nie byłoby to korzystne dla istnienia i rozwoju diecezjalnego duszpasterstwa. Rozważają oni bardziej pójście w kierunku agregacji instytutów lub zgromadzeń zakonnych mających w swoim charyzmacie pracę wychowawczą z młodzieżą w szkołach. Refleksje te zachęcają do odważnego zaangażowania się $\mathrm{w}$ działalność szkolnictwa katolickiego skutecznie służącego społeczeństwu poprzez rozwój kultury i humanizmu chrześcijańskiego.

Szósty rozdział napisany jest przez trzech autorów: Francesco Beneduce, Antonello Famà i Grazia Tagliavini. Weryfikują oni związek, jaki zachodzi między szkołami różnych zgromadzeń zakonnych i duszpasterstwem diecezjalnym. Podkreślają zaangażowanie i wrażliwość zakonów względem zadań duszpasterskich i ukazują trudności we współpracy. W badaniach analizowano głównie założenia wspólnot zakonnych i tworzenie wspólnot wychowawczych w szkołach poprzez integrację i uczenie odpowiedzialności.

Kontynuując podobną tematykę, Sante Redi Pol w siódmym rozdziale analizuje relacje między wspólnotą wychowawczą szkoły katolickiej i diecezjalnego duszpasterstwa. Autor podkreśla w swoim rozważaniu oryginalność doświadczeń pastoralnych i dynamikę działalności rozwojowej szkół. Wskazuje na te instytucje, które - mimo iż nie są bezpośrednio uzależnione od działalności Kościoła - to jednak opracowują projekt edukacyjny oparty na zasadach Ewangelii.

Kolejny rozdział, przedstawiony przez Carlo M. Fedeli, ukazuje relacje między szkołą katolicką i diecezjalnymi ruchami duszpasterskimi. Autor skupia się w szczególności nad rozwojem relacji między szkołami a ruchami kościelnymi i nowymi wspólnotami formacyjnymi. We wspólnotach tych wskazuje na aspekty pozytywne i negatywne w ramach życia Kościoła.

Edmondo Lanciarotta w rozdziale dziewiątym koncentruje się na ukazaniu sytuacji edukacyjno-pastoralnej w Triveneto (trzy regiony w północnych Włoszech). Zwraca on uwagę na różne typy szkół katolickich oraz ich oddziaływanie na zainteresowane podmioty w tym regionie. Podkreśla w swoim rozważaniu otwartość szkół na projekty edukacyjne, możliwości badań i eksperymentów mających na celu rozwój kształcenia i wychowania młodzieży oraz wzrost jakości pracy nauczycieli.

Ogólne wnioski zostały sformułowane przez G. Malizia, S. Cicatelli, C. M. Fedeli oraz V. Pieroni. Przedstawiają one kompleksowe omówienie podstaw, sytuacji i propozycji działań szkolnictwa katolickiego w aktualnej rzeczywistości włoskiej i kościelnej. Nowością omawianego tomu są załączniki, które ukazują konkretne dane dotyczące szkół katolickich i przedstawiają główne trendy i tendencje rozwojowe. 
Przedstawiana pozycja polecana jest szczególnie władzom szkolnym, specjalistom z zakresu edukacji, jak również animatorom pastoralnym na poziomie szkoły, regionu i kraju. Książka staje się kluczem do zrozumienia współczesnej szkoły katolickiej i jest jednocześnie interesującym wkładem w działalność szkolnictwa katolickiego i ośrodków szkolenia zawodowego o inspiracji chrześcijańskiej. Na podstawie zawartych w niej refleksji zauważa się, że szkoły katolickie, poprzez promowanie chrześcijańskiego stylu wychowawczego, stanowią „,wielkie bogactwo dla kraju” i Kościołów lokalnych.

Stanisław Wierzbicki*

\section{Mariusz Sztaba, Wychowanie społeczne w świetle nauczania Karola Wojtyly-Jana Pawla II, Towarzystwo Naukowe KUL, Katolicki Uni- wersytet Lubelski Jana Pawła II, Lublin 2012, ss. 618.}

DOI: http://dx.doi.org/I0.12775/PCh.2013.021

Wychowanie społeczne stanowi istotny aspekt działalności wychowawczej, co wynika przede wszystkim z faktu, że człowiek jest istotą społeczna, czyli dąży do życia i realizuje się w życiu wspólnie z innymi. Koncepcje wychowania społecznego mogą ulegać jednak zmianie w zależności od tego, jak rozumiana jest natura człowieka i jak definiowane jest społeczeństwo, czy jakie są uwarunkowania kulturowo-społeczno-gospodarcze życia człowieka na danym etapie jego historii. Również obecnie mamy do czynienia $\mathrm{z}$ dużą różnorodnością nurtów i kierunków wychowania społecznego. Efektem wprowadzenia ich w życie są różne sposoby funkcjonowania jednostki w społeczeństwie, od skrajnego indywidualizmu, który wiąże się instrumentalnym traktowaniem innego człowieka, do sposobu wyznaczanego przez kolektywizm, w którym jednostka podporządkowuje się grupie, nie próbując wpływać na sposób jej funkcjonowania. Koncepcja wychowania społecznego może się więc $\mathrm{w}$ skrajnych przypadkach przełożyć albo na destrukcję życia społecznego, albo na zagubienie człowieka w jego indywidualności i specyfice. Konieczna jest zatem nieustanna refleksja nad wychowaniem społecznym - przyglądanie się mu z różnych perspektyw, tak aby działalność wychowawcza, przeniknięta światłem rozumu, przyczyniała się do takiego rozwoju jednostki i społeczeństwa, który przynosi dobro samemu człowiekowi - istocie społecznej. Jedną z koncepcji wychowania społecznego zrekonstruować można na podstawie filozoficznej refleksji Karola Wojty-

* Ks. dr Mirosław Stanisław Wierzbicki SDB pracuje w Wydziale Nauk o Wychowaniu Papieskiego Uniwersytetu Salezjańskiego w Rzymie. 